Wawryków Agata, Korabiusz Katarzyna, Stecko Monika, Torbe Andrzej. Physiotherapeutic aspect of returning to sexual activity after childbirth. Journal of Education, Health and Sport. 2020;10(9):500-505. eISSN 2391-8306. DOI http://dx.doi.org/10.12775/JEHS.2020.10.09.060

https://apcz.umk.pl/czasopisma/index.php/JEHS/article/view/JEHS.2020.10.09.060

https://zenodo.org/record/4042191

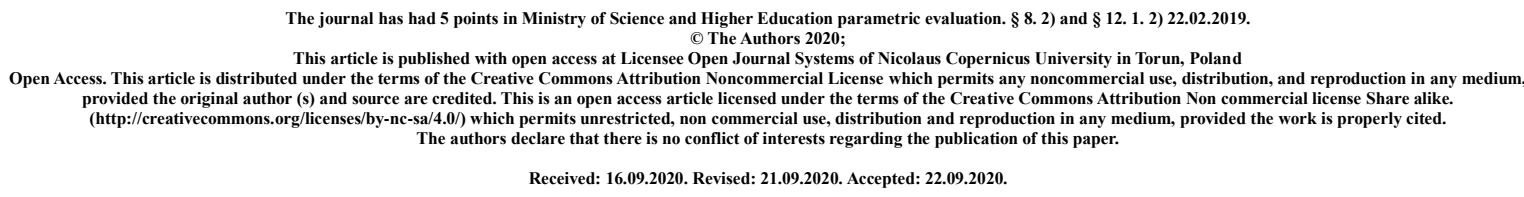

\title{
Physiotherapeutic aspect of returning to sexual activity after childbirth
}

\author{
mgr Agata Wawryków' ${ }^{1}$, mgr inż. Katarzyna Korabiusz' ${ }^{1}$, mgr Monika Stecko', \\ prof. dr hab. n. med. Andrzej Torbé ${ }^{2}$
}

${ }^{1}$ Pomorski Uniwersytet Medyczny w Szczecinie, Studium Doktoranckie Wydziału Nauk o Zdrowiu, ul. Żołnierska 54, 71-210 Szczecin

2 Pomorski Uniwersytet Medyczny w Szczecinie, Klinika Położnictwa i Ginekologii, ul. Powstańców Wlkp. 72, 70-111 Szczecin

\begin{abstract}
Returning to sexual intercourse after childbirth is a significant problem for many young parents. The most frequently recommended period of sexual absenteeism is the postpartum period. It is a period of regeneration of the body and return to full physical activity. There are many reasons for not engaging in sexual activity after childbirth. However, this article focuses on somatic causes, such as those that require the help of a urogynecological physiotherapist.
\end{abstract}

Key words: sexual activity, childbirth, pelvic floor dysfunction 


\begin{abstract}
Abstrakt
Powrót do współżycia seksualnego po porodzie stanowi istotny problem wielu młodych rodziców. Najczęściej zalecanym okresem absencji seksualne jest czas połogu. To okres regeneracji organizmu i powrotu do pełnej sprawności fizycznej. Przyczyn braku podejmowania aktywności seksualnej po porodzie jest wiele. Artykuł ten skupia jednak uwagę na przyczynach somatycznych, takich które wymagają pomocy ze strony fizjoterapeuty uroginekologicznego.
\end{abstract}

Słowa klucz: współżycie seksualne, poród, dolegliwości dna miednicy

\title{
Introduction
}

Sexual activity after childbirth is a significant problem faced by many young parents. This topic is often overlooked by those who provide postnatal care. There are no precise guidelines for starting sexual intercourse after childbirth. Most often, right after the birth of the child, the mother receives an order for sexual absence in the puerperium. This may be due to the risk of infections associated with the postpartum faeces, as well as the time it takes for a wound to heal after an episiotomy or a caesarean scar. At this time, the involution of the uterus also takes place, which can be strongly felt by the patients in the first days after delivery.

Due to the lack of precise guidelines, the authors of the publication suggest a safe return to sexual activity in women without perineal disruption, approximately 2-3 weeks after delivery and 4-8 weeks, and even later in women after incision or reconstruction of the perineum. ${ }^{1}$ Particular attention is paid to the 6th week after delivery, when the woman should be able to resume intercourse without pain and other ailments. ${ }^{2}$

\section{Somatic changes in women in the puerperium}

Undoubtedly, pregnancy and a previous childbirth bring many changes in the wellbeing, and often also in the health and functioning of the mother. A series of hormonal and functional changes occur in the body of a young mother, causing a significant decrease in energy. ${ }^{3}$ In the postpartum period, anatomical, morphological and functional changes gradually subside to the state of the organism before pregnancy. Systemic changes in the puerperium concern hormonal changes, the circulatory system, changes in the mammary glands and sexual organs. The puerperium also involves the healing process of postpartum wounds. ${ }^{4}$ The cleansing of the uterus in the first days after delivery may be accompanied by strong contractions. Pain in the perineal area, sometimes also in the sacrum, coccyx and / or the pubic symphysis, is very common in women after vaginal delivery.

\footnotetext{
${ }^{1}$ Sarah F. Peterson, Lisa M. Goldthwaite, Postabortion and Postpartum Intrauterine Device Provision for Adolescents and Young Adults, Journal of Pediatric and Adolescent Gynecology, 10.1016/j.jpag.2019.05.012, 32, 5, (S30-S35), (2019)

${ }^{2}$ Elena Serrano Drozdowskyj, Esther Gimeno Castro, Elena Trigo López, Inés Bárcenas Taland, Carlos Chiclana Actis, Factors Influencing Couples' Sexuality in the Puerperium: A Systematic Review, Sexual Medicine Reviews, 10.1016/j.sxmr.2019.07.002, (2019)

${ }^{3}$ Słomko Z., Opala T., Pisarska-Krawczyk M., Połóg [w:] Położnictwo i ginekologia, dz.cyt., s. 382

${ }^{4}$ Dziok, I., Kamińska, A., \& Płoch, K. (n.d.). Połóg jako sytuacja trudna w życiu kobiety
} 
In women after caesarean section, the pain most often affects the area of the wound itself. It is worth paying attention to the fact that many women struggle with other ailments about which little is said. Among the most commonly reported are chronic constipation and hemorrhoids, as well as weakness and stretching of the pelvic floor muscles, resulting in urinary and gas incontinence. Almost every woman in childbirth also reports various types of pain. Among the most frequently mentioned are problems with the lumbar spine, which most often teases during pregnancy and increases in the third trimester. In the postpartum period, hormonal changes occur, with a large loss of body weight and a change in the body's center of gravity. After giving birth, a woman permanently loads her spine by carrying her newborn baby, often with a car seat or stroller with it. The second most frequent dysfunction is the thoracic section. Its ailments most often result from a significant enlargement of the breasts of a nursing mother, as well as from adopting incorrect positions while carrying a newborn and breastfeeding. Breastfeeding is an activity that some mothers associate with a wonderful bonding time with their newborn and others with suffering and frustration. Many mothers who have difficulty in breastfeeding spend a lot of time stimulating milk secretion, latching on to the breast, and taking care of sore breasts and nipples. It happens that breastfeeding becomes a big problem affecting the emotional state of the mother.

In the postpartum period, problems such as: reduction of the reproductive organs, rectus abdominal muscle dehiscence, pubic symphysis and faecal incontinence are also reported.

\section{Emotional problems after childbirth}

Immediately after giving birth, a young mother is accompanied by a series of strong emotions. They are caused by the past delivery, a newborn baby, and also hormonal changes. A woman quite often struggles with pain, fatigue and other ailments. The aforementioned factors, as well as caring for a newborn baby, a sense of responsibility, sometimes also helplessness, cause a changeable mood, nervousness, and sometimes lower self-esteem in the young mother. On the 4-6th day after childbirth, due to hormonal changes and enormous changes in the life of parents, almost $80 \%$ of couples experience a mood swing called baby blues. This condition may last up to two weeks. Emotional changes in the first period after childbirth are also accompanied by drowsiness and severe fatigue. Baby blues may be a natural state, however, young parents should be taken care of and helped, because mood swings and fatigue that last too long can cause postpartum depression, especially in those who are predisposed to it. 
Many authors emphasize that biological, psychosocial, socio-demographic and socioeconomic factors also predispose to emotional disorders in women after childbirth. Partner as well as family conflicts and the level of stress are of great importance. ${ }^{56}$ One of the most common disorders is postpartum depression, which affects 30 to $75 \%$ of mothers and occurs in the first days after delivery, with the greatest intensity between the 3rd and 5th day. ${ }^{7}$,

\section{Reasons for giving up sexual activity}

While resignation from sexual activity in puerperium seems to be justified, there is a concern that young parents do not undertake it after the end of the puerperium. The way of giving birth, postpartum dysfunction, postpartum depression and breastfeeding have an influence on the decision to give up sexual activity. ${ }^{9}$ Very important factors that also determine the initiation of intercourse and the level of sexual satisfaction after childbirth are the way of pregnancy termination, the image of the mother's own body and her relationship with her partner. Other authors indicate that the reasons for postponing return to intercourse include fear, pain, lack of excitement, and embarrassment. ${ }^{10}$ Psychological care for a woman after childbirth seems to be indispensable, thanks to which it would be easier to understand and accept the changes caused by pregnancy and childbirth. A very important role is played by the community midwife who meets the woman and her newborn child during patronage visits. It is she who could spot women with emotional and somatic disorders, but also inform and educate about returning to sexual activity.

Recently, urogynecological physiotherapy has also played an important role in recognizing early ailments and disorders that undoubtedly affect the return to sexual activity. Many authors emphasize that in women after episiotomy, sexual intercourse is more painful than before pregnancy, and the frequency of orgasms also clearly decreases. ${ }^{11}$ Other authors note that most of the surveyed women felt differences during intercourse compared to the feelings before pregnancy. ${ }^{12}$

\footnotetext{
${ }^{5}$ Augustyniuk K, Rudnicki J, Grochans E, Jurczak A, Wieder-Huszla S, Szkup-Jabłońska M. Uczestnictwo w zajęciach Szkoły Matek i Ojców a częstość występowania zaburzeń emocjonalnych w okresie poporodowym. Med. Ogólna Nauki Zdr. 2013; 19(2): 138-141

${ }^{6}$ Morylowska-Topolska J, Makara-Studzińska M, Kotarski J. Wpływ wybranych zmiennych socjodemograficznych i medycznych na nasilenie objawów lękowych i depresyjnych w poszczególnych trymestrach ciąży. Psychiatr. Pol. 2014; 48(1): 173-186.

${ }^{7}$ Kaźmierczak M, Gebuza G, Gierszewska M. Zaburzenia emocjonalne okresu poporodowego. Probl. Pielęg. 2010; 18(4): 503-511

${ }^{8}$ Adewuya A. The maternity blues in Western Nigerian women: Prevalence and risk factors. Am. J. Obstet. Gynecol. 2005; 193: 1522-1525

${ }^{9}$ Leeman, Lawrence M., MD; Rogers, Rebecca G., MD Sex After Childbirth, Obstetrics \& Gynecology: March 2012 - Volume 119 - Issue 3 - p 647-655

${ }^{10}$ Kucala K., Huras H., Bereza K. (n.d.). Satysfakcja z życia seksualnego kobiet to porodzie [w:] https://ruj.uj.edu.pl/xmlui/handle/item/237026

${ }^{11}$ Kucala K., Huras H., Bereza K. (n.d.). Satysfakcja z życia seksualnego kobiet to porodzie [w:] https://ruj.uj.edu.pl/xmlui/handle/item/237026

${ }^{12}$ Kuźniar M., Dziubak M., Majewska-Szczepanik M. (n.d.). Satysfakcja z życia seksualnego kobiet po porodach oraz wybrane czynniki wptywajace na poziom tej satysfakcji. https://ruj.uj.edu.pl/xmlui/handle/item/242666
} 
Postpartum ailments significantly limiting the return to sexual performance are described in the literature quite briefly. In the physiotherapy office, special attention is paid to perineal discomfort. These include: the tenderness of the scar after the incision of the perineum, the enormous tension within the scar, as well as the pelvic floor muscles. The listed dysfunctions significantly limit women in everyday functioning, and they certainly also delay the return to sexual activity. Moreover, after vaginal delivery, patients report pain in the area of the coccyx. However, in the literature more often mentioned are very embarrassing problems such as: loss of urine, feces and / or gases resulting from pelvic floor muscle failure. It is worth paying attention to the fact that postpartum physiotherapy should be an indispensable element of care for a woman after childbirth. Highly qualified physiotherapeutic personnel is able to effectively get rid of these postpartum dysfunctions. In addition, the urogynecological physiotherapist will help the young mother introduce correct habits to everyday activities, appropriate positions for breastfeeding, educate them about returning to sexual activity and possible weight reduction, as well as choosing the right physical activity for her.

\section{Summary}

Sexual activity is an essential part of a relationship. The ability to experience parenthood as well as the way of perceiving one's own body are factors that influence the need for a relationship with a partner. Emotional and somatic feelings during the puerperium and later on may have a positive, but also negative impact on the desire to engage in sexual activity. Taking care of a woman after childbirth should be holistic. Urogynecological psychologists and physiotherapists should be located right next to the gynecologist and midwife. 


\section{Literature}

1. Sarah F. Peterson, Lisa M. Goldthwaite, Postabortion and Postpartum Intrauterine Device Provision for Adolescents and Young Adults, Journal of Pediatric and Adolescent Gynecology, 10.1016/j.jpag.2019.05.012, 32, 5, (S30-S35), (2019)

2. Drozdowskyj E.S., Gimeno Castro E., Trigo López E., Bárcenas Taland I., Chiclana Actis C., Factors Influencing Couples' Sexuality in the Puerperium: A Systematic Review, Sexual Medicine Reviews, 10.1016/j.sxmr.2019.07.002, (2019)

3. Słomko Z., Opala T., Pisarska-Krawczyk M., Połóg [w:] Położnictwo i ginekologia, dz.cyt., s. 382

4. Dziok, I., Kamińska, A., \& Płoch, K. (n.d.). Połóg jako sytuacja trudna w życiu kobiety

5. Augustyniuk K, Rudnicki J, Grochans E, Jurczak A, Wieder-Huszla S, SzkupJabłońska M. Uczestnictwo w zajęciach Szkoły Matek i Ojców a częstość występowania zaburzeń emocjonalnych w okresie poporodowym. Med. Ogólna Nauki Zdr. 2013; 19(2): $138-141$

6. Morylowska- Topolska J, Makara-Studzińska M, Kotarski J. Wpływ wybranych zmiennych socjodemograficznych i medycznych na nasilenie objawów lękowych i depresyjnych w poszczególnych trymestrach ciąży. Psychiatr. Pol. 2014; 48(1): 173-186.

7. Kaźmierczak M, Gebuza G, Gierszewska M. Zaburzenia emocjonalne okresu poporodowego. Probl. Pielęg. 2010; 18(4): 503-511

8. Adewuya A. The maternity blues in Western Nigerian women: Prevalence and risk factors. Am. J. Obstet. Gynecol. 2005; 193: 1522-1525

9. Leeman, Lawrence M., MD; Rogers, Rebecca G., MD Sex After Childbirth, Obstetrics \& Gynecology: March 2012 - Volume 119 - Issue 3 - p 647-655

10. Kucala K., Huras H., Bereza K. (n.d.). Satysfakcja z życia seksualnego kobiet to porodzie [w:] https://ruj.uj.edu.pl/xmlui/handle/item/237026

11. Kuźniar M., Dziubak M., Majewska-Szczepanik M. (n.d.). Satysfakcja z życia seksualnego kobiet po porodach oraz wybrane czynniki wpływające na poziom tej satysfakcji. https://ruj.uj.edu.pl/xmlui/handle/item/242666 